\title{
Energy Band Structure and Photocatalytic Property of Fe-doped $\mathrm{Zn}_{2} \mathrm{TiO}_{4}$ Material
}

\author{
Jum Suk Jang, ${ }^{\dagger}$ Pramod H. Borse, ${ }^{\dagger \ddagger}$ Jae Sung Lee, ${ }^{\dagger}$ Kwon Taek Lim, ${ }^{\S}$ Ok-Sang Jung, ${ }^{\sharp}$ Euh Duck Jeong, ${ }^{\text {P }}$ \\ Jong Seong Bae, ${ }^{\mathrm{P}}$ Mi Sook Won, ${ }^{\mathrm{P}}$ and Hyun Gyu $\mathrm{Kim}^{\mathrm{P}}{ }^{\times}$
}

\author{
${ }^{\dagger}$ Department of Chemical Engineering. Pohang Linversity of Science and Technologv, Pohang 790-784, Korea \\ ${ }^{\ddagger}$ Centre for Nanomaterials, International Advanced Research Centre for Powder Metallurgv and New Materials \\ (ARC International), Balapur PO, Hyderabad, AP, 500 005, India \\ 'Department of Imaging Sustem Engineering, Pukvong National Chiversitw, Busan 609-735. Korea \\ "Department of Chemistry (BK21), Pusan National Lniversity, Busan 627-706, Korea \\ ${ }^{\mathrm{P}}$ Busan Center, Korea Basic Science Institute, Busan 609-735. Korea. ${ }^{*}$ E-mail: hhghimiäkbsi.re.hr \\ Received September 1, 2009, Accepted November +. 2009
}

\begin{abstract}
$\mathrm{Zn}_{2} \mathrm{Ti}_{1-\mathrm{x}} \mathrm{Fe}_{\mathrm{S}} \mathrm{O}_{4}(0 \leq \mathrm{x} \leq 0.7)$ photocataly sts were sy'nthesized by polymerized complex (PC) method and investigated for its phy sico-chemical as well as optical properties. $\mathrm{Zn}_{2} \mathrm{Ti}_{1} \mathrm{Fe}_{\mathrm{K}} \mathrm{O}_{+}$can absorb not only UV light but also visible light region due to doping of $\mathrm{Fe}$ in the $\mathrm{Ti}$ site of $\mathrm{Zn}_{2} \mathrm{TiO}_{4}$ lattice because of the band transition from $\mathrm{Fe} 3 \mathrm{~d}$ to the $\mathrm{Fe} 3 \mathrm{~d}+\mathrm{Ti} 3 \mathrm{~d}$ hybrid orbital. The photocatalytic activity of $\mathrm{Fe}$ doped $\mathrm{Zn}_{2} \mathrm{TiO}_{4}$ samples for hydrogen production under UVV light irradiation decreased with an increase in Fe concentration in $\mathrm{Zn}_{2} \mathrm{TiO}_{4}$. Consequently, there exists an optimized concentration of iron for improved photocatalytic activity under visible light $(\lambda \geq 420 \mathrm{~nm})$
\end{abstract}

Key Words: Fe doped $\mathrm{Zn}: \mathrm{TiO}_{4}$, Polymerized complex method, Photocatalysis, Visible light. Hydrogen production

\section{Introduction}

Photocataly'sts could convert solar energy' into chemical energy by producing hydrogen gas from water or hydrogen containing compounds. ${ }^{1 / 5}$ Thus hydrogen production by use of photocatalysts has recently received much attention because of the depletion of fossil fuel source and related environmental problems. $\mathrm{Zn}_{2} \mathrm{TiO}_{4}$ has been a promising material for the photocatalytic water splitting as well as photocatalytic oxidation reaction under UV light because of its higher reduction potential and lower oxidation potential. ${ }^{6}$

But. $\mathrm{Zn}_{-} \mathrm{TiO}_{4}$ has a wide band gap $(3.1 \mathrm{eV})$ and thus don ${ }^{\circ}$ show the photocatalytic activity under visible light. ${ }^{6}$ Since visible light accounts for the largest portion ( $\mathrm{ca} .46 \%$ ) of the solar spectnum. visible light-driven photocataly'sts are needed for hydrogen production from water as well as the decomposition of toxic compounds. One promising approach to develop new photocatalysts is the tuning or modification of the optical properties of UV light active catalysts by doping, as demonstrated in $\mathrm{La}$.

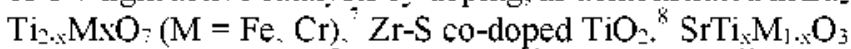

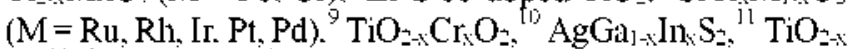
$\mathrm{C}_{\mathrm{x}}{ }^{12.13}$ or $\mathrm{TiO}_{2 . \times \mathrm{N}} \mathrm{N}^{14}$ for cation and anion doping.

Here we have tailored the band gap of $\mathrm{Zn}_{2} \mathrm{TiO}_{4}$ by doping of Fe metal ion with Ti site in $\mathrm{Zn}_{2} \mathrm{TiO}_{4}$ crystal lattice using the poly merized complex reaction and characterized it using UVVis diffuse reflectance spectroscopy (UV-Vis DRS) and X-ray diffraction (XRD). This work further reports the photocatalytic activity for hydrogen production under UV and visible light irradiation $(\hat{\gamma},>+20 \mathrm{~nm})$.

\section{Experimental}

Preparation of nanoerystalline $\mathrm{Zn}_{2} \mathrm{Ti}_{1-\mathrm{x}} \mathrm{Fe}_{\mathrm{x}} \mathrm{O}_{4}(0 \leq \mathrm{x} \leq \mathbf{0 . 7})$. Nanocry'stalline $\mathrm{Zn}_{2} \mathrm{Ti}_{1} . \mathrm{Fe}_{.} \mathrm{O}_{4}$ was synthesiszed by the $\mathrm{PC}$ met- hod according to the same procedure in our previous work. ${ }^{1516}$ Zinc nitrate hexahydrate $\left(\mathrm{Zn}\left(\mathrm{NO}_{3}\right)=6 \mathrm{H}_{2} \mathrm{O} .98 .0 \%\right.$, Aldrich), iron nitrate hydrate $\left(\mathrm{Fe}\left(\mathrm{NO}_{3}\right)_{3} \cdot 9 \mathrm{H}_{2} \mathrm{O} .98 \%\right.$. Aldrich), titanium (IV) isopropoxide ( $\mathrm{Ti}\left[\mathrm{OCH}\left(\mathrm{CH}_{3}\right)_{2}\right]_{+} .97 \%$, Aldrich), ethy lene glycol $\left(\mathrm{C}_{2} \mathrm{H}_{6} \mathrm{O}_{2}\right.$. Kanto Chemicals). citric acid $\left(\mathrm{C}_{6} \mathrm{H}_{8} \mathrm{O}\right.$. Wako) were used as starting materials. The citric acid (CA) was added into ethylene glycol under constant agitation, at temperature of $60-70^{\circ} \mathrm{C}$. Ethylene glycol (EG) was added to the mixture to yield a mass proportion of $60 \% \mathrm{CA}$ to $40 \% \mathrm{EG}$. Next. titanium (IV) isopropoxide was dissolved in citric acid-EG solution and then the salts of zinc nitrate hexahydrate and iron nitrate hydrate were dissolved in the above mixture to obtain metal citrate complex. Finally. the nixture was kept on the hot plate $\left(80^{\circ} \mathrm{C}\right)$ until it became a transparent solution. The well mixed solution was then heated at $130^{\circ} \mathrm{C}$ for several hours to obtain a polymeric gel. The viscous polymeric product was pyrolyzed at about 300 . $500{ }^{\circ} \mathrm{C}$ to form the precursor powders. Thus obtained powder was pressed in the form of pellets, which were calcined at $1200{ }^{\circ} \mathrm{C}$ for $5 \mathrm{~h} \mathrm{in}$ an electric furnace to obtain nanocrystalline $\mathrm{Zn}_{2} \mathrm{Ti}_{1} . \times \mathrm{Fe}_{2} \mathrm{O}_{4}$. On the other hand. for the purpose of comparison. $\mathrm{TiO}_{2-\mathrm{x}} \mathrm{N}_{\mathrm{x}}$ nanoparticle was also prepared by the hydrolytic synthesis method (HSM). ${ }^{1 \text { ? }}$

Characterization. $\mathrm{Zn}_{2} \mathrm{Ti}_{1-\mathrm{x}} \mathrm{Fe}_{\mathrm{x}} \mathrm{O}_{4}(0 \leq \mathrm{x} \leq 0.7)$ samples thus obtained were characterized by X-ray Diffractometer (Mac Science Co.. M18XHF). X-ray diffraction (XRD) results were compared with the Joint Committee Powder Diffraction Standards (JCPDS) data for phase identification. The band gap energy and optical property of the as-prepared materials was measured by UV-Visible diffuse reflectance spectrometer (Shimadzu. UV 2401). The morphology was deternined by scanning electron microscopy (SEM Hitachi. S-2460N) and high-resolution transmission electron microscopy (HR-TEM. Philips. CM 200)

Photocatalytic activity. The rate of $\mathrm{H}_{2}$ evolution was determined for water-methanol solution (distilled water $70 \mathrm{~mL}$ and 
methanol $30 \mathrm{~mL}$ ) containing $0.1 \mathrm{~g}$ cataly st. The concentration of $\mathrm{H}_{2}$ was analyzed by gas chromatography equipped with a thermal conductivity detector (molecular sieve 5-A column and Ar carricr). Before both reactions. I $\mathrm{wt} \%$ of Pt was deposited on photocatalysts by photodeposition method under uv $(\lambda \geq$ $210 \mathrm{~nm})$ and visible light $\left(\lambda_{r} \geq 400 \mathrm{~nm}\right)$.

\section{Results and Discussion}

Structural characterization of the samples was investigated to compare their cristallization behaviors with respect to the calcination temperatures. Figure I shows the XRD pattenis of

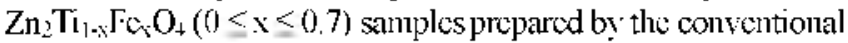
solid state reaction method. All the samples showed an inverse spincl with a lattice constant of $8.48 \mathrm{~A}$ and space group $\mathrm{Fd} 3 \mathrm{~m}$, ${ }^{18}$ But, undoped $\mathrm{Zn}_{2} \mathrm{TiO}_{4}$ and $\mathrm{Zn}_{2} \mathrm{Ti}_{(1,45} \mathrm{Fe}_{0.035} \mathrm{O}_{4}$ samples represent pure crystal structure without $\mathrm{Fe}_{2} \mathrm{O}_{3}$ crystal phase among the assynthesized samples. With the increase in the concentration of iron $(\mathrm{x}-0.05)$, X-ras diffraction pattem of $\mathrm{Fc}_{2} \mathrm{O}_{3}$ in $\mathrm{Zn}_{2} \mathbf{T i}_{1-\mathrm{s}}$ $\mathrm{Fe}_{4} \mathrm{O}_{+}(0 . \mathrm{I} \leq \mathrm{x}<0.7)$ samples clearly appear the Figure $\mathrm{I}$. This indicates that only snall amount of iron ion into $\mathrm{Zn}_{2} \mathrm{TiO}_{4}$ crystal structure can be substituted into the lattice of 'Ti site in $\mathrm{Zn}: \mathrm{TiO}_{4}$ crvstal structure

The optical properties were studicd by UV-Vis diffuse reflectance (UV-DR) spectroscopy for iron doped $\mathrm{Zn}_{2} \mathrm{TiO}_{4}$ samples with different contents. Figure 2 shows the UV-Visible diffuse reflectance spectra of $\mathrm{Zn}_{2} \mathrm{Ti}_{1-\mathrm{x}} \mathrm{Fc}_{\mathrm{x}} \mathrm{O}_{4}(0 \leq \mathrm{x} \leq 0.7)$ samples $(0 \leq$ $x \leq 0.7)$. In case of undoped $\mathrm{Zn}_{2} \mathrm{TiO}_{4}$ sample, absorption edge appeared near $400 \mathrm{~nm}$ corresponding to $3.1 \mathrm{cV}$. consistent with the literature. "However. the absorption spectra of $\mathrm{Fe}$ doped $\mathrm{Zn}_{2}-$ $\mathrm{TiO}_{4}$ samples exhibit new absorption shoulder in visible light region. In general, the absorption edge of $7 n_{2} \mathrm{TiO}_{4}$ around 400 num was ascribed to the band transition from $O 2 p$ to $\mathrm{Zn} 4 \mathrm{~s}$. $\Lambda$ dditionally; the absorption of Fe doped $\mathrm{Zn}_{2} \mathrm{TiO}_{4}$ samples was based on the transition from $\mathrm{Fe}_{\mathrm{g}}$ to $\mathrm{Fe} 4 \mathrm{~s}$. In this case, the interband may exist between the conduction and valenee band of $\mathrm{Zn}_{2} \mathrm{TiO}_{4}$.

Figure 3 shows scanning elcetron microscopy (SEM) images of $\mathrm{Zn}_{2} \mathrm{Ti}_{1-\mathrm{x}} \mathrm{Fe}_{\mathrm{x}} \mathrm{O}_{+}(\mathrm{x}=0.0,0.05,0.1,0.2)$ samples with different content of iron calcined at $1200^{\circ} \mathrm{C}$ for $5 \mathrm{~h}$. respectively. All samples represent the morphology of a well-developed cry stal and the grain size of as-synthesized samples shows a similar value of $5-10 \mu \mathrm{m}$. But. with increasing the Fe doping level into the lattice site of $\mathrm{Ti}$ in $\mathrm{Zn}_{2} \mathrm{TiO}_{4}$ cristal structure. there exists the impurity crystal phase with small grain size. The existence of small grains possibly affects the photocatalỵtic activity of asprepared samples.

We investigated the photocataly tic hydrogen production from methanol-water solution using undoped $\mathrm{Zn}_{2} \mathrm{TiO}_{4}$ and $\mathrm{Zn}_{2} \mathrm{Ti}_{1-x}$ $\mathrm{Fc}_{\mathrm{x}} \mathrm{O}_{4}(\mathrm{x}=0.05,0.1)$. and $\mathrm{TiO}_{2 \times \mathrm{N}} \mathrm{V}_{\mathrm{v}}$ samples under uv and visible light iradiation. Table I shows the results of $\mathbf{H}_{2}$ evolution as well as respective band gaps of the samples calculated from respective DRS spectra. All the samples showed the photocataly tic activity for hydrogen production from methanol-water solution under uv light irradiation $(\lambda \geq 210)$. Among the as-synthesized samples. undoped $\mathrm{Zn}_{2} \mathrm{TiO}_{4}$ photocatalyst showed the highest photocatalytic activity as compared to other samples. The Fe doped sample, $\mathrm{Zn}_{2} \mathrm{Tin}_{10,5} \mathrm{Fc}_{0,63} \mathrm{O}_{4}$. with low doping level only showed $\mathrm{H}_{2}$ production as high as $6.2 \mathrm{mmol} / \mathrm{gcat} \cdot \mathrm{hr}$ under visible

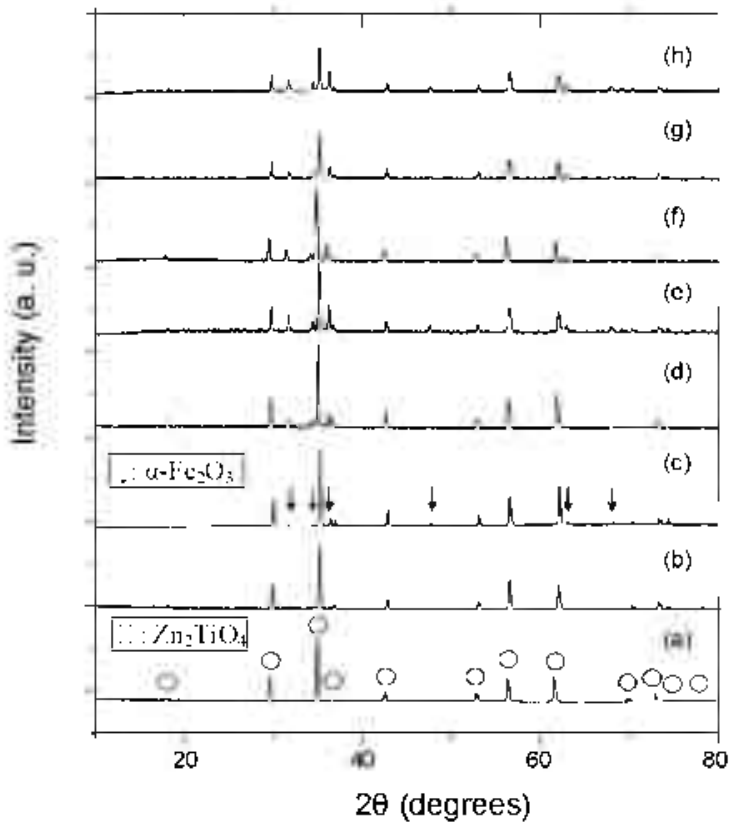

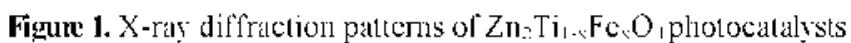
for $x=(a) 0$. (b) 0.05. (c) 0.1. (d) (0.2. (c) 0.3. (1) 0.4. (g) 0.6. and (h) 0.7 .

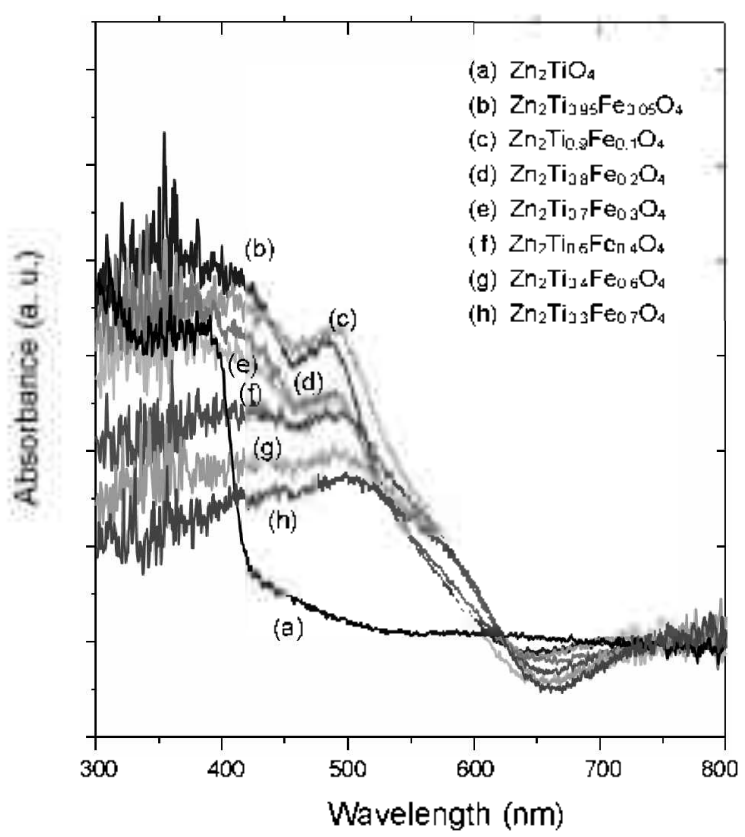

Figure 2. UV-x is diffuse reflectance spectra of $Z_{n} T_{2} i_{1-i} F c_{2} O_{\text {. }}$ photocataly sis for $\mathrm{x}=$ (a) 0 . (b) 0.05 . (c) 0.1 , (d) 0.2 . (c) 0.3 . (f) 0.4 . (g) 0.6 . and $(\mathrm{h}) 0.7$

light irradiation $(2 \geq 420 \mathrm{~nm})$. But. $\mathrm{Zn}_{2} \mathrm{Ti}_{0.9} \mathrm{Fc}_{0.1} \mathrm{O}_{4}$ and $\mathrm{TiO}_{2-2} \mathrm{~N}_{\mathrm{x}}$ samples showed a trace anount of $\mathrm{H}_{2}$ production. This indicates that the $\mathrm{Zn}_{2} \mathrm{Ti}_{10.95} \mathrm{Fe}_{0.015} \mathrm{O}_{4}$ seens to be an optimum concentration which could lead to the proper bandgap as well as band position for producing hydrogen gas as compared to other samples. Possibly, the Fe doping concentration higher than $\mathrm{Zn}_{2} \mathrm{Ti}_{0.05} \mathrm{Fc}_{10.05} \mathrm{O}_{+}$ $(\mathrm{x}=0.05)$ leads to $\mathrm{Fc}_{2} \mathrm{O}_{3}$ as an impurity phase. which could play a role of electron transfer medium towards a positive 

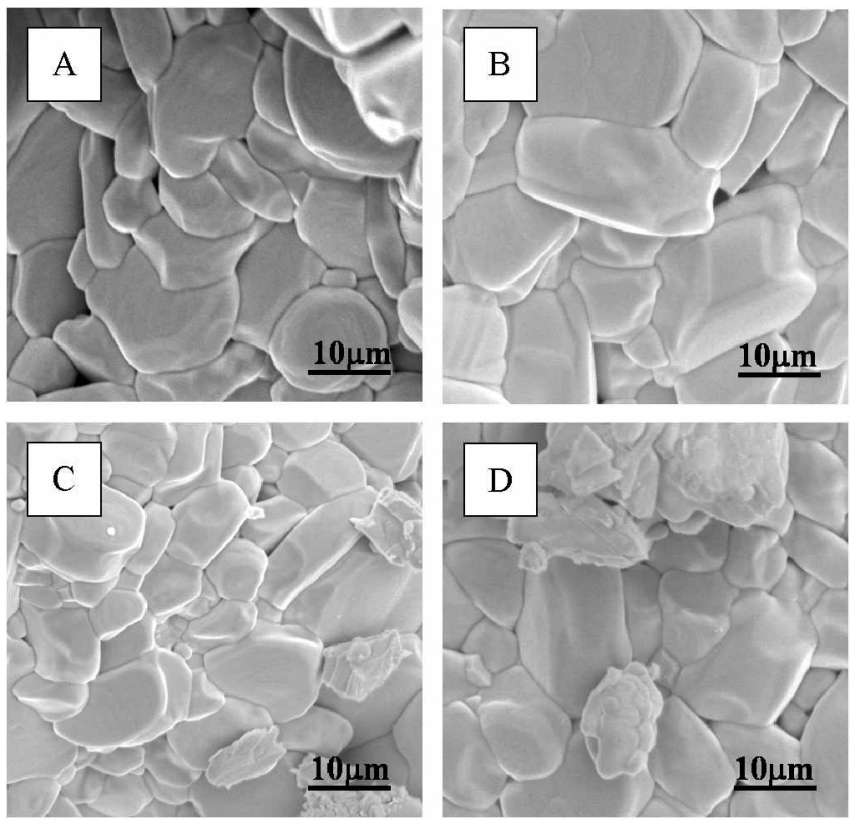

Figure 3. SEM inages of $Z_{11} \mathrm{Ti}_{1-\mathrm{x}} \mathrm{Fe}_{\mathrm{S}} \mathrm{O}_{4}$ samples for $\mathrm{x}=$ (a) 0 . (b) 0.05 . (c) 0.1 , and (d) 0.2 .

Table 1. Photocatalytic $\mathrm{H}_{2}$ production from methanol-water solution over $1 w 0 \mathrm{Pt} / \mathrm{ZnTi}_{1 \cdot \mathrm{x}} \mathrm{Fe}_{\mathrm{x}} \mathrm{O}_{4}(\mathrm{x}=0.0,0.05,0.1)$ and $1 \mathrm{w} \% \mathrm{Pt} / \mathrm{TiO}_{2 \cdot \mathrm{x}} \mathrm{N}_{x}$ samples.

\begin{tabular}{|c|c|c|c|c|}
\hline \multirow[b]{2}{*}{ Catalyst } & \multicolumn{2}{|c|}{ Energy band gap } & \multicolumn{2}{|c|}{$\begin{array}{l}\mathrm{H}_{2} \text { evolution } \\
\text { (mmol/gcat.hr) }\end{array}$} \\
\hline & $\frac{\mathrm{Eg}}{(\mathrm{eV})-1}$ & $\underset{(\mathrm{eV})-2}{\mathrm{Eg}}$ & $\begin{array}{c}\text { UV light } \\
\text { iradiation } \\
(\lambda>210 \mathrm{~mm})(\end{array}$ & $\begin{array}{l}\text { Visible lihgt } \\
\text { imadiation } \\
(\lambda>420 \mathrm{~mm})\end{array}$ \\
\hline $\mathrm{Pt} / \mathrm{Zn}_{2}=\mathrm{TiO}_{4}$ & 3.10 & - & 140 & 0 \\
\hline $\mathrm{Pt} / \mathrm{Zn1}_{2} \mathrm{Ti}_{0.05} \mathrm{Fe}_{0.05} \mathrm{O}_{4}$ & 3.10 & 2.48 & 116 & 6.2 \\
\hline $\mathrm{Pt} / \mathrm{Zn}_{2} \mathrm{Ti}_{0.0} \mathrm{Fe}_{0.1} \mathrm{O}_{4}$ & 3.10 & 2.48 & 11 & Trace \\
\hline $\mathrm{Pt} / \mathrm{TiO}_{-\mathrm{x}} \mathrm{N}_{\mathrm{x}}$ & 3.20 & $2.7 \hat{3}$ & 8 & Trace \\
\hline
\end{tabular}

potential more than the reduction potential of $\mathrm{H}_{2}$.

Figure 4 shows time curve of the photocatalytic hydrogen production over $\mathrm{Zn}_{2} \mathrm{Ti}_{2.9} \mathrm{Fe}_{c_{1}} \mathrm{O}_{4}$ for $15 \mathrm{~h}$ with intermittent $\mathrm{N}_{2}$ gas purging every $3 \mathrm{~h}$ (dotted line). There was no noticeable reduction in activity during the first two nuns for $6 \mathrm{~h}$. This implies that the $\mathrm{Zn}_{-} \mathrm{Ti}_{1} \mathrm{Fe}_{5} \mathrm{O}_{4}$ sample may be stable in water-methanol solution during photocatalytic reaction.

XPS measurements were carried out to analyze the oxidation state of $\mathrm{Fe}$ atoms in $\mathrm{Zn}=\mathrm{Ti}_{1}, \mathrm{Fe}_{1}, \mathrm{O}_{4}$ photocataly st. Figure 5 shows the XPS survey spectrum of $\mathrm{Zn}_{2} \mathrm{Ti}_{1.95} \mathrm{Fe}_{0.65} \mathrm{O}_{4}$ sample. which contains $Z \mathrm{n}, \mathrm{Ti}, \mathrm{O}$. C and Fe elements. with photoelectron peaks appearing at binding energies of 1022 ( $\mathrm{Zn} 2 \mathrm{p}_{3: 2}$ ). 459 ( $\mathrm{Ti}$ $\left.2 \mathrm{p}_{\mathrm{s}: \mathrm{z}}\right) .53 \mathrm{l}(\mathrm{O} \mathrm{ls}$ ) and $285 \mathrm{eV}(\mathrm{C} 1 \mathrm{~s})$ and a weak photoelectron peak at $711 \mathrm{eV}\left(\mathrm{Fe} 2 \mathrm{p}_{3}\right)$. The inset in Figure 5 presents the core level spectra of the $\mathrm{Fe} 2 \mathrm{p}_{3: 2}$ region of corresponding sample revealing that the peak at $711 \mathrm{eV}$ is symmetrical and can be ascribed to the trivalent oxidation state of $\mathrm{Fe}\left(\mathrm{Fe}^{3-}\right)$.

Figure 6A shows the bandgap position of $\mathrm{Zn}_{2} \mathrm{Ti}_{1}{ }_{5} \mathrm{Fe}_{0} \mathrm{O}_{4}$ and $\mathrm{TiO}_{-\mathrm{X}} \mathrm{N}_{\mathrm{x}}$ photocatalysts as suggested from the results of

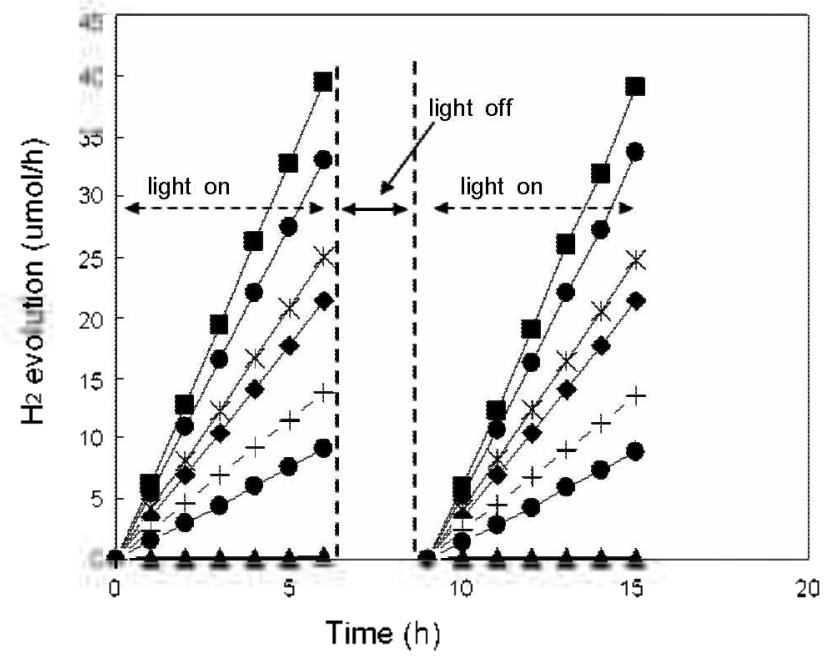

Figure 4. Time courses of hydrogen production over various $\mathrm{Zn}_{\mathrm{n}} \mathrm{Ti}_{1-x}$ $\mathrm{Fe}_{2} \mathrm{O}_{4}$ for $\mathrm{x}=(\mathbf{\square}) 0.05,(\mathbf{0}) 0.04,(x) 006,(\diamond) 0.07,(+) 0.03,(\mathrm{O})$ 0.02 and $(\boldsymbol{\Delta}), \mathrm{TiO}_{2-x} \mathrm{~N}_{x}$ photocatalysts.

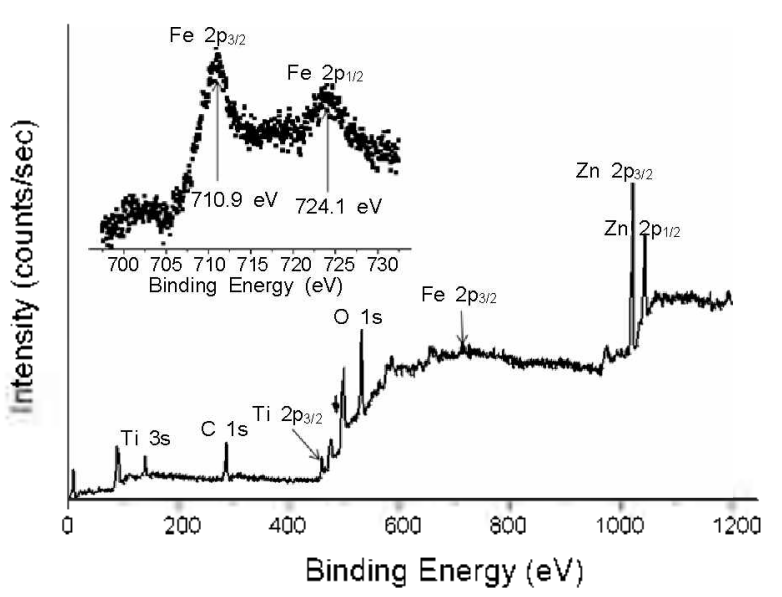

Figure 5. XPS survey spectrum of $\mathrm{Zn}_{2} \mathrm{Ti}_{l_{194} 4} \mathrm{Fe}_{0<15} \mathrm{O}_{4}$ sample. The insert shows the XPS core-level spectra of $\mathrm{Fe} 3 \mathrm{~d}$ in $\mathrm{Zn}_{2} \mathrm{Ti}_{0.95} \mathrm{Fe}_{6.05} \mathrm{O}_{4}$ sample.

undoped $\mathrm{Zn}_{2} \mathrm{TiO}_{4}$ and $\mathrm{TiO}_{2}$ reported by Matsumoto et al. ${ }^{6}$ and UV-DRS data of doped two materials. ${ }^{1 *}$ The bandgap energy of $\mathrm{Zn}_{2} \mathrm{Ti}_{9}, \mathrm{Fe}_{1} \mathrm{O}_{4}$ and $\mathrm{TiO}_{-\mathrm{x}} \mathrm{N}_{\mathrm{K}}$ are $c a .2 .48,2.73 \mathrm{eV}$, respectively. In general. in case of $\mathrm{Fe}$-doped material an interband is formed between the conduction and valence band of undoped material. ${ }^{\text {T }}$ Thus, the doped material could absorb visible light due to the transition from interband to the conduction band of the original material. With knowledge of the band position of the undoped material. here we propose the schematic of band positions of doped material as shown in Figure 6A. Figure 6B represents the schematic describing the mechanism for photocatalytic ly drogen production over $\mathrm{Zn}_{2} \mathrm{Ti}_{(1955} \mathrm{Fe}_{1,105} \mathrm{O}_{4}$ from methanol-water solution under visible light irradiation $(\lambda \geq 420 \mathrm{~nm})$. $\mathrm{Zn}_{2} \mathrm{Ti}_{1,99} \mathrm{Fe}_{1, \ldots 5} \mathrm{O}_{4}$ photocataly st produced $\mathrm{H}_{2}$ gas in the presence of aqueous methanol-water solution under visible light. Thus. in the case of $\mathrm{Pt} / \mathrm{Fe}$-doped $\mathrm{Zn}_{2} \mathrm{TiO}_{4}$, an electron excited is to the conduction band due to sufficiently high reduction potential to reduce $\mathrm{H}^{-}$ion and a hole in the valence band also has lower oxidation potential for $\mathrm{CH}_{3} \mathrm{OH}$ degradation to $\mathrm{CO}_{2}$. $\mathrm{H}_{2}$ gas was 
(A)

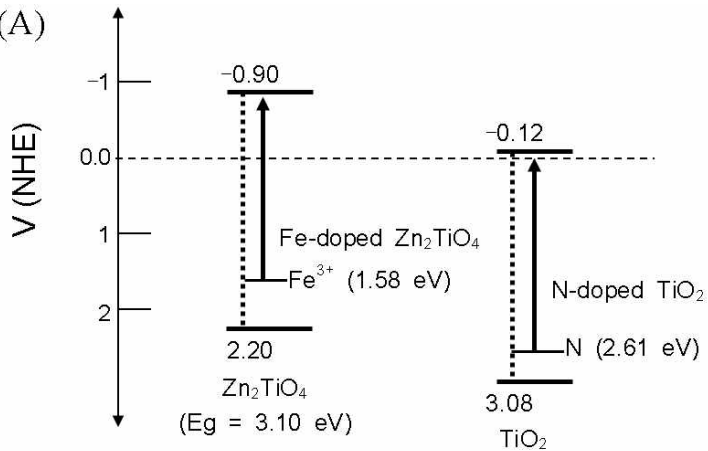

$(\mathrm{Eg}=3.20 \mathrm{eV})$

(B)

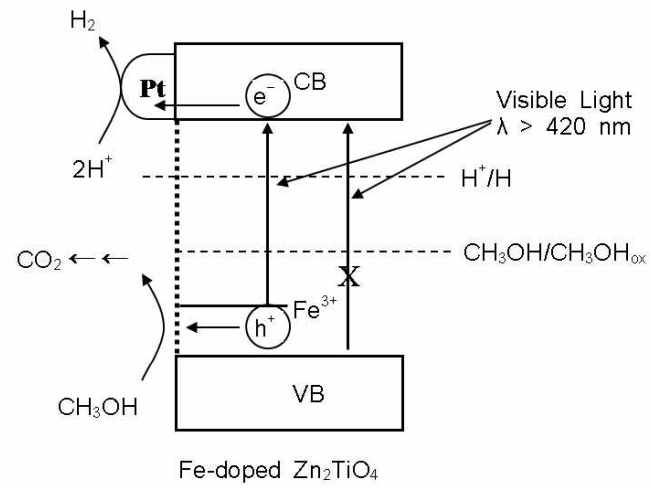

Figure 6. $(\Lambda)$ The bandgap posilion o[ $\mathrm{Zn1}_{2} \mathrm{Ti}_{1-\mathrm{\gamma}} \mathrm{Fex} \mathrm{O}_{1}$ and $\mathrm{TiO}_{2 \times \mathrm{X}} \mathrm{N}_{\mathrm{x}}$ photocalalysts. (B) The whematic describing the mechanism for photocatalytic hydrogen production trom methanol-uater solution.

generated only when the fonmation of an ohmic junction bet-

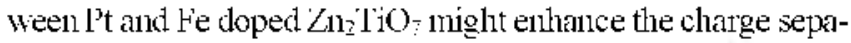
ration. Therefore, Fe doped $\mathrm{Zn}_{2} \mathrm{TiO}_{4}$ could be applied lor photocatalytic reaction that requires a higher reduction potential as well as lower oxidation potential.

\section{Conclusions}

$\mathrm{Zn}_{2} \mathrm{li}_{1} \mathrm{Fe}_{\mathrm{N}} \mathrm{O}_{4}$ pholocalalysts were successfully prepared by the polymerized complex method. New band gap in the visible light range was obtained by $\mathrm{Fe}$ doping in $\angle \mathrm{n}_{2} \mathrm{TiO}_{4}$. $\angle \mathrm{n}_{2} \mathrm{Ti}_{0}$ y $\mathrm{Fe}_{0.05} \mathrm{O}_{4}$ sample with low doping level was synthesized without impurity phase such as $\mathrm{Fe}_{2} \mathrm{O}_{3}$ and only showed the photoca- talytic activity under visible light irradiation $(\lambda \geq 420 \mathrm{~nm})$. Further increase of the amount of $\mathrm{F}$ ' $\mathrm{C}$ in $\mathrm{Zn}_{2} \mathrm{IiO}_{1}$ led to the formation of $\mathrm{Fe}_{2} \mathrm{O}_{3}$ crystal phase. Therefore, it is considered that Fe doping could play an important role in reducing the bandgap and showing the photocalalytic activity in the system of $2 \mathrm{n}_{2} \mathrm{liO}_{4}$ under visible light imadiation.

Acknowledgments. This work has been supported by KBSI grant T29320. MKF-RTI04-0201, KOSIF grant (NCRCP, R 152006-(022-01002-0), Hydrogen Energy R\&L) Center, Korea.

\section{Reference}

1. Lcc. J. S. Catal. Sum Asia. 2005. 9. 217.

2. Kudo. A.: Miscki. Y. Chem. Soc. Rev. 2009. 38.253.

3. Maeda. K.: Takala. T.: Hara M.: Sailo. N.: Inouc, Y.: Kobayashi. H.: Domen. K. J. Am. (Thom. Soc 2005, 127. 8286

4. Kim. H. G.: Hwang. D. W.: J ee. J. S.: J. Am Chem. Soc. 2004. 126 8913.

5. Jang J. S.: Ji. S. M.: Bac. S. W.: Son H. C.: Lee. J.S. J. Photochth. Photobiol.d: (hom. 2007. 18s. 112.

6. Matsumoto. Y. J. Solid State (7ham 1996, 126. 227.

7. Hwang. D. W. Kim. H. G.: Iee T. S. Kill. J.: J.i. W : Oh.S. H.: J. Phis Chem. 2005. B109, 2093.

8. Kim S. W.: Khan. R: Kim T. J: Kim W. Bull Konen C/km Soc. 2008. 29. 1217 .

9. Bac. S. W.: Borsc. P. II.; Lce. J. S. Appl Phys Lett. 2008, 92, 104107

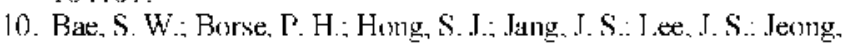
L. D.: Ilong T. L.: Yoon. J. II.: Jin, J. S.: Kim. Il. G.J. Korean Plnis. Soc. 2007. 51. S22.

11. Subramanian, L.: Bacg J.: Kalc. B. B.: Lec. S. M.: Moon, S.; Kong, K. Bull Sorzon Chem Soc. 2007, 28, 2089.

12. Khan, S. UJ.; AI-Shahry, M. M.; Ingler, JT., W. B. Science 2002, 297,2243 .

13. Sakthivel, S.: Kisch, I1.: Angen: Chem. Int Ed 2003. 42. 4908.

14. Ashai. R.: Ohwaki, l': Noli, K.: Taga, Y. Science 2001. 293, 269.

15. Kim II. G.: H Wang. D. W.: Bac. S. W.: Jung. J. II.: Lec. J. S. Catu. Lett. 2003, 91, 193.

16. Jung. F. D.: Borse P. H. Jang J S.; I .ee, J S - Cho, C. R.; Bae I. S.: Park S.: Jung, O. S.: Ry'l S. M. Kim, I1. G. J. Vamosei. Natotech. $2008,9,3568$

17. Jang. J. S.: Kim. II. Gi: Ji, S. M.: Bac. S. W.: Jung J. 11.; Shon. B. H. I ee, J. S. J. Solid Siate ( Them. 2006, 179, 1067.

18. Rankin, R. B.:Campos, A.: Tian, H.; Siriwardane, R.; Roy, A.: Spivey, J. J.: Sholl. 1). S.; Johnson, J. K. J. Am. Cerm. Soc. 2008. $9 i, 584$ 